\title{
Doleansie 100 jaar gelede
}

PROF. V. E. d'ASSONVILLE

In 1886 het tientalle gemeentes in die Hervormde Kerk in Nederland die hiërargiese juk van die sinode met sy kerkreglemente afgegooi. Hulle het getreur oor die toestand.

Nou weet ons meer van die naam Doleansie. In 1886 was dit 'n beweging in die groot Nederlands Hervormde staatskerk. Mense het getreur o,or die treurige toestand in die kerk. Hulle was hoogs ontsteld. Vrysinnigheid het oor jare heen die oorhand gekry. $\mathrm{Na}$ God se Woord is nie meer geluister nie. Die Gereformeerde Belydenis is verloën. Die ideologie van Modernisme het die kerk oor geneem. 'n Groot kerklike botsing tussen die waarheid en die leuen was onvermydelik. Dekades lank sou die konflik smeul.

\section{WAT WAS DIE WESE VAN DIE DOLEANSIE?}

Daaroor kan 'n mens dik boeke lees. Die kortste definisie wat die akademikus kan gee om die Doleansie raak te tipeer, is die volgende:

Die Doleansie was die spontane verset van kerkrade en lidmate in die Hervormde Kerk in Nederland teen die kerkreglemente waardeur die Modernisme die oorhand gekry het.

\section{WAT WAS DIE MODERNISME?}

In die $19 \mathrm{e}$ eeu was dit 'n stroming in die kerk en teologie wat gebreek het mel die historiese Christendom en met name met die beginsels van die 16e eeuse Reformasie. Die Gereformeerde Belydenis ooreenkomstig die Sinode van Dordrecht (1618-1619) is opsygeskuif. Die Modernisme was 'n algemene jag na vernuwing - nuwe dinge in die plek van die ou gereformeerde ortodoksie ( = die suiwer leer).

Onder die baie vrysinnige dominees onder invloed van die gees van die Franse rewolusie wat Sondag die "arme vermaerde skape" met intellektualistiese vrysinnige "klippe" probeer voed het, was dit veral sekere teologiese professore wat die voorperde van die Modernisme was. Hier dink ons veral aan J. H. Scholten (leermeester van A. Kuyper!) en A. Kuenen. Vanuit die teologiese fakulteit van Leiden het Scholten met sy "Leer der Hervormde Kerk" (1848) as 'n "moderne" dogmatiek onder gereformeerde vlag sy tienduisendes onder die kerkvolk via die kansels verslaan. Kuenen het weer met 'n nuwe soort eksegese (Skrifverklaring) gekom, die sogenaamde "literêr-historiese kritiek" op die Bybel. Die Bybel is nie meer so gesagvol soos wat die Gereformeerde Belydenis beweer nie, het hy probeer bewys. Die gevolge was fataal. Preke was meer vertoonvensters sonder die egte ware. In die katkisasieklasse het Darwin se ewolusionisme die werklike feite van die Heilige Skrif verdring. Die menslike rede, sy ervaring, sy eksperiment in die laboratorium het die finale kenbron vir die waarheid geword. 
Kinders is gedoop in die naam van geloof, hoop en liefde. God het slegs 'n "Opperwese" geword.

Dit was maar slegs 'n kwessie van tyd toe die ergste begin gebeur het:

Die wonder van die Bybel is geloën.

Ook die geestelike wonder (wedergeboorte) is verwerp.

Die skepping uit niks is beskou as 'n dwaasheid.

Die sondeval word as tradisiegeloof afgemaak.

Die godheid van Christus word bevraagteken.

Jesus is slegs die ideaal-mens om as voorbeeld na te volg.

\section{DIE HIERARGIESE STRUKTUUR DEUR KERKREGLEMENTE}

Die kanonne van Waterloo het nog skaars stil geword toe die Franse finaal verslaan is, of die gees van die Franse Rewolusie behaal tog ' $n$ verpletterende o.orwinning oor die Gereformeerde Kerk. Dit was met "Het Algemeen Reglement" van koning Willem I waardeur die gereformeerde Dordtse Kerkorde finaal gelikwideer is. Daardeur het die kerkregering 'n hiërargiese struktuur gekry. Sinodale kommissies het nou "pouse" geword wat van bo-af die kerkrade met dwang voorgeskryf het. Bokant die kerkraad staan die permanente klassikale bestuur. Hulle ontvang weer hulle bevele van die provinsiale kerkbestuur en die groot "base" is die "sinodale kommissie".

In die praktyk het die stryd van die Doleansie teen hierdie kerkbesture se rigoristiese hantering van reglemente gewoed.

Die saak waaroor die stryd egter gegaan het is die handhawing van die suiwer Skriftuurlike leer, die gesag van God se Woord en die gereformeerde belydenis.

Dit was die konflik tussen ortodoksie (= die suiwer dogma) en die vrysinnigheid van die Modernisme.

\section{TOTALE DEURBRAAK VAN DIE VRYSINNIGHEID}

Een of ander tyd sou die ligte windjies van verandering en vernuwing om die gereformeerde leer aan te tas, tot orkaansterkte aangroei. Erens sou dominees wat al op die randjie van die afgrond van dwaling beweeg, begin tuimel. Vroeër of later was die kerklike konflik onder die gewone kerkvolk, die "kleine luyden" soos Kuyper hulle genoem het, onvermydelik. Verskeie besluite van hiërargiese kommissies sou die onrus vererger:

In 1878 word artikel 38 van die kerkreglement so gewysig dat verskil van geloofsoortuiging van die gereformeerde belydenis nie ' $n$ rede is om 'n katkisant vir "aanneme" af te wys nie. (Ook die begrip "aanneming" i.p.v. belydenisaflegging is 'n produk van die Modernisme.) En as 'n kerkraad dit tog waag om vrysinnige katkisante weg te wys, dan gaan hulle eenvoudig na 'n buurgemeente met 'n vrysinnige dominee, word daar lidmaat en kom met "attestasie" as volle lidmaat weer terug. Hierdeur het die konflik opgelaai. En die kerkbesture was voortdurend aan die kant van die vrysinniges.

Verder het die stryd oor die "quia"- of "quatenus-standpunte onafwendbaar die kerkvolk in twee kampe gejaag. Die ou gereformeer- 
de waarheid was dat proponente in die ondertekeningsformulier verklaar dat hulle die belydenis handhaaf omdat (quia) dit ooreenkom met God se Woord. Na die Algemene Kerkreglement van 1816 is die ondertekeningsformulier verander na in soverre (quatenus) dit ooreenkom met Gods Woord. In wese kom dit dan daarop neer dat 'n predikant self kan kies watter waarhede van die Belydenisskrifte hy wil aanvaar en watter hy wil verwerp.

Die gevolge is tot vandag toe in die gereformeerde wêreld fataal.

\section{OP DIE VOORPUNT VAN DIE STRYD}

Die Doleansie het nie maar sommer oornag ontstaan nie. Jare van stryd deur kampvegters vir die Gereformeerde Belydenis in die Hervormde Kerk het daaraan voorafgegaan.

Ons dink dadelik aan daardie pragtige christen-staatsman Groen van Prinsterer. Sy meedoënlose stryd vir handhawing van die Gereformeerde Belydenis was 'n heldhaftige poging om die kerkvolk voortdurend bewus te maak van hulle dure roeping. Reeds in 1842 het hy sy eerste "adres" tot die Sinode gerig waarin hy handhawing van die Gereformeerde Belydenis eis. Tot sy dood in 1876 (tien jaar voor Doleansie) het sy pen nooit gerus om die onbybelse vrysinnigheid in die kerk te striem nie.

En dan dr. Abraham Kuyper! Met reg kan verklaar word dat hy die siel van die Doleansie was. Met De Heraut as kerklike blad het Kuyper week na week die kerkvolk op die reformatoriese pad terug na die Skrif en Belydenis gelei. Hier was die pen inderdaad magtiger as die swaard. Sy "Traktaat van de Reformatie der Kerken" is tot vandag toe nog 'n skitterende appèl op alle gereformeerdes se gewetens.

Ook dic Vrije Universiteit as 'n Universiteit vir Christelike Hoër Onderwys opgerig in 1881 het die vesting en arsenaal vir regsinnigheid geword. Die grondslag was klinklaar en helder: Die Drie Formuliere van Enigheid. Met reg was dit die groot bolwerk en vesting van die Doleansie.

\section{DIE EERSTE DOLERENDE GEMEENTES}

Op 4 Januarie 1886 het die klassikale bestuur 'n groep ouderlinge van Amsterdam geskors omdat hulle geweier het om attestasies aan katkisante van vrysinnige predikante uit te reik en omdat hulle bepaal het dat die stoflike goedere die eiendom van die gemeente is. Hierdie ingrypende daad was die begin van die konflik wat later sou uitbars.

Op 2 Februarie word die hele kerkraad van Kootwijk geskors omdat hulle 'n proponent van die Vrije Universiteit beroep het. Hierop het die gemeente onder leiding van $\mathrm{dr}$. W. van den Bergh hulle losgemaak van die sinodale reglemente en die sinodemag.

In Friesland was die eerste gemeente wat hulle losgemaak het van die sinodale hiërargie en 'n dolerende ( $=$ 'n treurende) gemeente in die Hervormde kerkverband geword het, Reitsum, onder leiding van ds. Johannes Ploos. Hulle het hulle veral verset teen die ondertekeningsformulier vir proponente waardeur 'n poort vir onbeperkte 
leervryheid in die kerk geskep is. Baie belangrik is die gemeente van Reitsum se standpunt:

Hier is geen afskeiding nie en dit is geen nuwe kerk nie.

Die kerk is die plaaslike kerk en nie die groot organisasie met reglemente en sinode-strukture nie.

Die onwettige juk van die Koninklike Reglement van 1816 word afgeskud.

Ons daad is geen breuk nie, maar die herstel van die waarheid. Nog voor die einde van 1886 het die langdurige stryd van die kerkraad van Amsterdam tot 'n klimaks gekom. Volgehoue vertoë vir' terugkeer tot die Dordtse Kerkorde en die Drie Formuliere van Enigheid het niks gehelp nie. Inteendeel: 80 kerkraadslede waaronder die bekende A. Kuyper word met een stem(!) meerderheid deur die klassikale bestuur geskors; Dr. Hoedemaker se verontwaardiging is heftig: "Gaan na die Sjah van Persië en na 'n swart koning van Afrika... vertel aan hulle dat 80 kerkraadslede met een stem geskors is!"

Vanuit Amsterdam is die groot stryd van die Doleansie gevoer. Binne 'n jaar het meer as 100 gemeentes gevolg. Hier sien ons dan ook die groot verskil met die Afskeiding van 1834: Destyds is dit slegs enkele gemeentes wat hulle losmaak van die hiërargie en dwalings met slegs vyf predikante.

Die Doleansie egter, was die grootste kerkreformasie na meer as twee eeue sedert die Sinode van Dordrecht (1618-1619).

WAT WAS DIE BETEKENIS VIR DIE GEREFORMEERDE KERKE?

Twee jaar voordat die Doleansie deurgebreek het, verskyn Kuyper se magistrale "Tractaat van de Reformatie der Kerken" (1884). Hier het ons die eintlike program van die Doleansie. Trouens, iemand wat hierdie "Tractaat" nog nie gelees het nie, weet nog nie mooi waaroor dit in die Doleansie gegaan het nie. Daarin word die "gewichtige werk der reformatie van onze kerken" aan die orde gestel. Met 'n strakke sisteem behandel Kuyper in volgorde die Formasie, die Deformasie en die Reformasie van die kerk.

En alles trek saam rondom twee enkele punte:

1. Reformasie is die terugkeer na God se Woord.

2. Reformasie is die terugkeer na die suiwer belydenis van die kerk. Die Skrif is die Woord van God - so skryf Kuyper in een van sy artikels. En die ware gemeente van Jesus Christus bely deur alle eeue en bely dit vandag nog dat die Skrif God se Woord is. "Dat is haar dogma", roep hy uit, "haar leerstuk. Een dogma in de egte zin. Niet het spitsvondig resultaat ener dorre, afgetrokken scholastiek. Neen, het is de juiste formulering van een door haar geestelijke ervaring bewust geworden zedelijke waarheid".

Op 'n ander plek verset hy hom teen die humanisme van sy tyd waardeur die kerk verwêreldlik word deur die mens se idees: Die gemeente moet weer die rykdom van die Skrif ontdek, weer uit die Skrif gaan dink, weer uit die Skrif gaan preek, weer uit die Skrif gaan bid...

En dit is die mees tipiese van die Doleansie: Die kerk is weer vanuit die Skrif beskou. Die preke was weer vanuit die Skrif en die ge 
meente is weer volgens die Skrif geregeer en daarom is met hierdie reformasie weer radikaal teruggegryp na die Skriftuurlike Dordtse Kerkorde wat - so het die befaamde Doleansie kerkregdeskun dige prof. Rutgers bewys - vierkantig in sy beginsels gegrond is op die Heilige Skrif.

En dan die stryd vir die Gereformeerde belydenis.

Daarvoor het die staatsman Groen van Prinsterer reeds dekades lank gestry en hiervoor het Kuyper pleidooi gelewer. Lees maar slegs Rullman se "Strijd om kerkherstel". Die punt van die Bely. denis was die eintlike Thermopilae vir die Gereformeerde Kerk. As God se Woord die kompas is, was die manne van die Doleansie nie so nalef om sonder die goeie landkaart van die beproefde gereformeerde belydenis te gaan en dit op ligsinnige manier te minag nie. Kuyper skryf soos volg:

"De kerk heeft een konfessie. Onze kerken onderscheiden zich daardoor van het konfessionsloze Anabaptisme.

De kerk plaatst zich bij het uitspreken van haar konfessie op de bodem der Schrift.

Het gaat hier niet om de bodem die men zelf legt, maar om de bodem, waarop de gemeente staat, n.l. de Schrift. Van een staan boven, van een staan naast de Schrift, kan voor het gereformeerde hart nooit kwestie zijn. De Schrift is de bodem, waarin de konfessie der gemeente wortelt, waaraan ze haar autoriteit ontleent. Aan de Schrift moet ze voor elk hart en elke dag examinabel blijven. Dit werd steeds door onze vaderen beleden."

En met hierdie twee groot beginsels oor die Heilige Skrif en die Gereformeerde Belydenis, was die dolerende kerke bereid om te staan en te val. En met hierdie twee beginsels het daar 'n nuwe terugkeer, 'n nuwe reformasie langs die hele front van die Nederlandse volkslewe posgevat. Dink aan die dinamiese $\mathrm{krag}$ van die Vrije Universiteit met sy duidelike grondslag: Die Drie Formuliere van Enigheid. Dink aan die stryd van die Antirewolusionêre Party. Dink aan die ywer vir die Christelike Onderwys, ens. In Suid-Afrika het die Vrije Universiteit op sy beurt weer 'n eksponent in die PU vir $\mathrm{CHO}$ gevind.

Een saak is baie duidelik: In die kerkgeskiedenis sal die beweging van die Doleansie in die Gereformeerde wêreld altyd as een van die grootste reformatoriese dade bly staan - met 'n selfs onberekenbare invloed tot in baie lande. 